\title{
Characterization of non-methane hydrocarbons in Asian summer monsoon outflow observed by the CARIBIC aircraft
}

\author{
A. K. Baker ${ }^{1}$, T. J. Schuck ${ }^{1}$, F. Slemr ${ }^{1}$, P. van Velthoven ${ }^{2}$, A. Zahn ${ }^{3}$, and C. A. M. Brenninkmeijer ${ }^{1}$ \\ ${ }^{1}$ Atmospheric Chemistry Division, Max Planck Institute for Chemistry, Mainz, Germany \\ ${ }^{2}$ Royal Netherlands Meteorological Institute, de Bilt, The Netherlands \\ ${ }^{3}$ Institute for Meteorology and Climate Research, Karlsruhe Institute of Technology, Karlsruhe, Germany
}

Received: 15 June 2010 - Published in Atmos. Chem. Phys. Discuss.: 29 July 2010

Revised: 13 December 2010 - Accepted: 30 December 2010 - Published: 18 January 2011

\begin{abstract}
Between April and December 2008 the CARIBIC commercial aircraft conducted monthly measurement flights between Frankfurt, Germany and Chennai, India. These flights covered the period of the Asian summer monsoon (June-September), during which enhancements in a number of atmospheric species were observed in the upper troposphere over southwestern Asia. In addition to in situ measurements of trace gases and aerosols, whole air samples were collected during the flights, and these were subsequently analyzed for a suite of trace gases that included a number of $\mathrm{C}_{2}-\mathrm{C}_{8}$ non-methane hydrocarbons. Non-methane hydrocarbons are relatively short-lived compounds and the large enhancements in their mixing ratios in the upper troposphere over southwestern Asia during the monsoon, sometimes more than double their spring and fall means, provides qualitative evidence for the influence of convectively uplifted boundary layer air. The particularly large enhancements of the combustion tracers benzene and ethyne, along with the similarity of their ratios with carbon monoxide and emission ratios from the burning of household biofuels, indicate a strong influence of biofuel burning to NMHC emissions in this region. Conversely, the ratios of ethane and propane to carbon monoxide, along with the ratio between i-butane and n-butane, indicate a significant source of these compounds from the use of fossil fuels, and comparison to previous campaigns suggests that this source could be increasing. Photochemical aging patterns of NMHCs showed that the CARIBIC samples were collected in two distinctly different regions of the monsoon circulation: a southern region where air masses had been recently influenced by low level contact and a northern region, where air parcels had
\end{abstract}

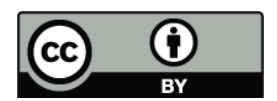

Correspondence to: A. K. Baker (angela.baker@mpic.de) spent substantial time in transit in the upper troposphere before being probed. Estimates of age using ratios of individual NMHCs have ranges of 3-6 days in the south and 9-12 days in the north.

\section{Introduction}

During summer in the Northern Hemisphere the Asian summer monsoon is the dominant meteorological feature, spanning longitudinally from Southeast Asia to Afghanistan and latitudinally from the Indian Ocean to Northern China. Onset is typically in early June, with northwestern propagation through July and August and recession in September (IMD, 2008; Joseph et al., 2006; Wang et al., 2009). Monsoon circulation is characterized by the southwesterly Somali jet in the lower to mid-troposphere, and anticyclonic flow in the mid- to upper troposphere and in the lowermost stratosphere (Krishnamurti and Bhalme, 1976; Hoskins and Rodwell, 1995; Hsu et al., 1999; Fujinami et al., 2004; Krishnamurti et al., 2008). The monsoon is associated with persistent strong convection over South Asia, primarily over India and the Bay of Bengal, which can rapidly transport boundary layer air to the upper troposphere, and anticyclonic flow in the upper troposphere is coupled with enhanced troposphere to stratosphere transport (Chen et al., 1995; Traub and Lelieveld, 2003; Fu et al., 2006). The deep convection and associated circulation patterns of the monsoon have been suggested to be an important pathway for polluted boundary layer air to reach the upper troposphere and lower stratosphere (UT/LS) (Randel et al., 2010). From here, pollution can be advected over other regions, or further uplifted in the stratosphere. 
Recent satellite observations of trace gases have shown strong chemical isolation within the UT/LS monsoon anticyclone, resulting in a monsoon "signature" for chemical constituents. Water vapor (Fu et al., 2006; Randel and Park, 2006), methane (Park et al., 2004; Xiong et al., 2009), nitrogen oxides (Park et al., 2004) and carbon monoxide (Fu et al., 2006; Park et al., 2008) are all elevated within the monsoon anticyclone, while ozone shows a minimum (Randel and Park, 2006; Liu et al., 2009); increased levels of ethane $\left(\mathrm{C}_{2} \mathrm{H}_{6}\right)$, ethyne $\left(\mathrm{C}_{2} \mathrm{H}_{2}\right)$, hydrogen cyanide $(\mathrm{HCN})$, methyl chloride $\left(\mathrm{CH}_{3} \mathrm{Cl}\right)$ and carbonyl sulfide (OCS) have also been observed (Park et al., 2008; Randel et al., 2010). Enhancements in trace gases have been observed between $\sim 10$ and $20 \mathrm{~km}$, with maximum values for longer lived compounds observed around $15 \mathrm{~km}$, and for shorter lived compounds around $13 \mathrm{~km}$ (Park et al., 2008). Satellite observations also suggest that deep convection is most frequent in July and August, but reaches higher in May and June (Devasthale and Fueglistaler, 2010).

While there exists an increasing number of satellite observations of trace gases in the UT/LS isolated within the monsoon anticyclone, in situ measurements of composition are scarce, and most studies during the monsoon have been limited to ground and ship-based campaigns without complimentary aircraft observations, consisting primarily of measurements relevant to monsoon meteorology rather than chemical composition (Sanjeeva Rao, 2005; Bhat and Narashima, 2007). In fact, there is a lack of measurements of trace gases in this region during all seasons. Ground-based measurements are limited to a handful of studies, focusing on either large urban areas in India (Lal et al., 2009; Sahu and Lal, 2006a) or rural/background measurements (Lal et al., 2000, 2006; Sahu and Lal, 2006b). The largest study of chemical composition in this region was INDOEX (Indian Ocean Experiment), which took place during February and March of 1999 (Lelieveld et al., 2001). The campaign consisted of a comprehensive suite of trace gas and aerosol measurements from ground-based, ship and aircraft platforms, and provides the basis for current knowledge of atmospheric composition in the region.

Model studies show that transport of air out of the monsoon anticyclone is predominantly to the west, with air masses being transported to the upper troposphere over the Arabian Peninsula and the Mediterranean (Lawrence et al., 2003; Lawrence and Lelieveld, 2010). Transport of pollutants to the east is less substantial than westward transport, particularly in light of the large contribution of East Asian pollution to trans-Pacific Asian outflow. Results from the MINOS (Mediterranean Intensive Oxidant Study) campaign in August of 2001 showed a significant impact of outflow of pollutants from the monsoon circulation on the composition of the upper troposphere over the Mediterranean during summer (Scheeren et al., 2003; Lelieveld et al., 2002), with elevated concentrations of non-methane hydrocarbons (NMHCs) and other trace gases.
In the troposphere NMHCs contribute to the formation of photochemical ozone, and can also affect the oxidative capacity of the atmosphere through their reaction with hydroxyl radical $(\mathrm{OH})$. Non-methane hydrocarbons have a wide range of sources, both anthropogenic and biogenic, and their atmospheric concentrations have considerable spatial and temporal variations, which are dependent on source strengths and removal processes. Many individual compounds have common sources (e.g. fossil fuel use, biomass and biofuel burning), sometimes having unique, source specific, relationships to one another, making them useful tracers for identifying sources contributing to the composition of a particular air parcel. The primary removal process of NMHCs is reaction with $\mathrm{OH}$, and the rates of reaction vary significantly between compounds, with lower molecular weight, saturated compounds generally having the longest lifetimes. With lifetimes ranging from a few hours to several weeks, timescales of NMHC removal are comparable to regional and intercontinental transport times of air masses. This feature, combined with their common emission sources and relatively invariable emission ratios, make certain NMHCs useful when investigating the degree of photochemical processing of an air parcel. The ratio between two NMHCs having different chemical lifetimes can be used to estimate transport times, as this relationship is dependent on the degree of photochemical processing (McKeen and Liu, 1993; Parrish et al., 1992, Roberts et al., 1984; Rudolph and Johnen, 1990). The utility of using NMHC "photochemical clocks" has been examined by a number of investigators, and the framework for examination of the $\mathrm{C}_{2}-\mathrm{C}_{5}$ alkanes to study photochemical aging has been particularly well characterized (McKeen and Liu, 1993; Parrish et al., 1992; Parrish et al., 2007; Helmig et al., 2008).

In this work we investigate the influence of the monsoon on the composition of NMHCs in the upper troposphere over Asia using measurements from whole air samples collected during CARIBIC (Civil Aircraft for the Regular Investigation of the atmosphere Based on an Instrument Container; www.caribic-atmospheric.com) flights between Frankfurt, Germany (FRA) and Chennai, India (MAA) before, during and after the monsoon season. Observations of NMHCs are discussed in the context of understanding their composition in the plume as well as understanding their sources. We also discuss photochemical processing and air mass ages.

\section{Technical and analytical details}

The CARIBIC project is a long-term atmospheric measurement program based on the use of an instrument container deployed on a monthly basis aboard a Lufthansa Airbus 340-600 for a series of four long-distance flights between Frankfurt, Germany and various destinations. Between April and December 2008 the CARIBIC container was installed 


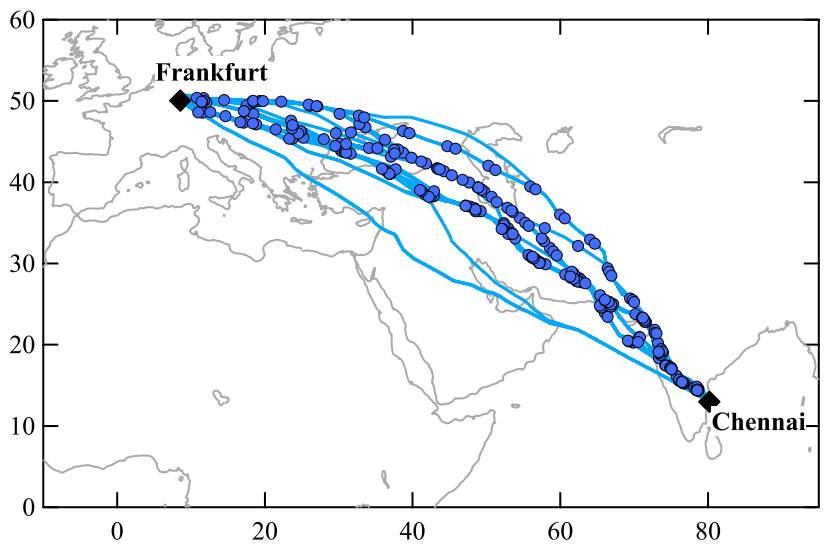

Fig. 1. CARIBIC flight routes between Frankfurt, Germany (FRA) and Chennai, India (MAA). Solid lines show the flight paths and filled circles indicate locations of whole air sample collection. The monsoon region is located south of $40^{\circ} \mathrm{N}$, and only those samples collected south of this are considered here (Schuck et al., 2010).

each month for two consecutive round-trip flights between Frankfurt, Germany (FRA) and Chennai, India (MAA). During this period, whole-air sample collection only took place during the first round-trip flight each month (FRA to MAA and MAA to FRA) to achieve higher temporal and spatial resolution with the limited number (28) of available sampling flasks. Figure 1 shows the flight tracks and sampling locations for all flights between FRA and MAA, and it can be seen that they varied relatively little between months. CARIBIC flights are conducted at commercial aircraft cruising altitudes, which are typically between 10 and $12 \mathrm{~km}(250-200 \mathrm{hPa})$ and averaged $\sim 11 \mathrm{~km}$ during FRAMAA flights. This places the aircraft within the monsoon anticyclone when over southwestern Asia during the monsoon season.

The CARIBIC instrument package is fully automated and during each flight carries out a variety of in-situ trace gas and aerosol measurements; a detailed description of its contents and operation can be found in Brenninkmeijer et al. (2007). Also housed in the instrument container are systems for the collection of aerosol and whole-air samples, which are analyzed upon return to the laboratory, and it is the analysis of NMHCs in the whole air samples that forms the basis of the work presented here. Detailed descriptions of CARIBIC sample collection and NMHC measurements can be found in Schuck et al. (2009) and Baker et al. (2010), respectively, and will only be described briefly here.

The whole-air sampler consists of a pumping unit and two sampling units (Triggered Retrospective Air Collector, TRAC) each of which houses 14 2.7 L glass sampling flasks, making the total number of samples collected per month 28. TRAC samples are collected along the flight routes at pre-determined, evenly spaced intervals; during collection of samples on FRA-MAA flights this corresponded to sam- pling intervals of $\sim 35 \mathrm{minu}$, or about $\sim 480 \mathrm{~km}$ between samples. Filling times are between 30 and $90 \mathrm{~s}$, with an average of $45 \mathrm{~s}$, corresponding to a spatial coverage between 7 and $21 \mathrm{~km}$ (10 km average) during collection of each sample. After the flight the TRACs are removed from the CARIBIC measurement container and samples are analyzed at different laboratories for NMHCs (Baker et al., 2010), greenhouse gases (Schuck et al., 2009), halocarbons (O'Sullivan, 2007) and the ${ }^{13} \mathrm{C} /{ }^{12} \mathrm{C}$ and ${ }^{18} \mathrm{O} /{ }^{16} \mathrm{O}$ isotopic ratios of $\mathrm{CO}_{2}$ (Assonov et al., 2009).

Whole air samples are analyzed for NMHCs using an HP6890 gas chromatograph (GC) coupled with a flame ionization detector (FID), where, prior to analysis, a 11 (STP) aliquot of sample is pretreated by drying followed by cryogenic pre-concentration and cryo-focusing. A suite of 20 compounds is measured, consisting of the $\mathrm{C}_{2}-\mathrm{C}_{8}$ alkanes, ethyne and the BTEX aromatics (benzene, toluene, ethylbenzene and the xylenes). Calibration of NMHCs is based on individual compound response factors determined from analysis of a synthetic mixture of NMHCs (accuracy of $\pm 2 \%$ ) purchased from the National Physical Laboratory (NPL, United Kingdom). Analytical precisions are compound dependent, and are less than $2 \%$ for ethyne and the $\mathrm{C}_{2}-\mathrm{C}_{6}$ alkanes, and less than $6 \%$ for all other compounds. While 20 compounds are measured, many are frequently below their detection limits (between 1 and 3 pptv); for this reason we focus on measurements of $\mathrm{C}_{2}-\mathrm{C}_{5}$ alkanes, ethyne and benzene in this work (Table 1).

A number of trace gases are measured continuously during each flight and these are sampled through the same inlet line as used for the collection of the TRAC samples. For each TRAC sample corresponding values of other trace gases measured during the flights are determined by integrating high resolution results from continuous measurements over the flask sampling period. Continuous measurements cited in this work are carbon monoxide $(\mathrm{CO})$ and ozone $\left(\mathrm{O}_{3}\right)$ (Brenninkmeijer et al., 2007). Carbon monoxide is measured using a vacuum ultraviolet fluorescence instrument at a time resolution of $1 \mathrm{~s}$ with a precision of $0.7 \mathrm{ppbv}$. Measurements of $\mathrm{O}_{3}$ are made using a dual-beam UV-photometer with a time resolution of $4 \mathrm{~s}$, having a precision of the larger of $0.3 \mathrm{ppbv}$ or $0.3 \%$ and a total uncertainty of $1.5 \%$. The CARIBIC container also houses a proton transfer mass spectrometer (PTRMS) for the measurement of acetone and acetonitrile. Unfortunately, data for acetonitrile (a useful biomass/biofuel burning tracer) are not available for the July flights, and had a high level of noise during August, making the data unusable for the period under consideration for the monsoon NMHC signatures and source identification.

For each flight meteorological analyses and backwards trajectory calculations are performed based on ECMWF re-analyzed data determined along the flight track (van Velthoven, 2009). Wind fields are calculated at a $1^{\circ} \times 1^{\circ}$ resolution for $6 \mathrm{~h}$, and meteorological data along the flight track are interpolated from wind field data at 1 min time steps. The 
Table 1. Analytical information and rates of reaction with hydroxyl radical $\left(k_{\mathrm{OH}}\right)$ for non-methane hydrocarbons considered in this work.

\begin{tabular}{|c|c|c|c|c|}
\hline \multicolumn{2}{|c|}{ Compound } & \multirow{2}{*}{$\begin{array}{r}\text { Detection } \\
\text { Limit }^{\mathrm{a}}\end{array}$} & \multirow{2}{*}{$\begin{array}{r}\text { Precision }^{\mathrm{a}} \\
0.2 \%\end{array}$} & \multirow{2}{*}{$\begin{array}{r}\begin{array}{r}k_{\mathrm{OH}}(298 \mathrm{~K}) \\
\mathrm{cm}^{3} \mathrm{molec}^{-1} \mathrm{~s}^{-1}\end{array} \\
2.5 \times 10^{-13, b}\end{array}$} \\
\hline ethane & $\left(\mathrm{C}_{2} \mathrm{H}_{6}\right)$ & & & \\
\hline propane & $\left(\mathrm{C}_{3} \mathrm{H}_{8}\right)$ & 1 pptv & $0.8 \%$ & $1.1 \times 10^{-13, b}$ \\
\hline n-butane & $\left(\mathrm{n}-\mathrm{C}_{4} \mathrm{H}_{10}\right)$ & $1 \mathrm{pptv}$ & $0.3 \%$ & $2.2 \times 10^{-12, b}$ \\
\hline i-butane & $\left(\mathrm{i}-\mathrm{C}_{4} \mathrm{H}_{10}\right)$ & $1 \mathrm{pptv}$ & $0.1 \%$ & $2.3 \times 10^{-12, b}$ \\
\hline n-pentane & $\left(\mathrm{n}-\mathrm{C}_{5} \mathrm{H}_{12}\right)$ & 1 pptv & $0.4 \%$ & $3.8 \times 10^{-12, b}$ \\
\hline i-pentane & $\left(\mathrm{i}-\mathrm{C}_{5} \mathrm{H}_{12}\right)$ & $1 \mathrm{pptv}$ & $0.3 \%$ & $3.9 \times 10^{-12, b}$ \\
\hline benzene & $\left(\mathrm{C}_{6} \mathrm{H}_{6}\right)$ & $3 \mathrm{pptv}$ & $2.3 \%$ & $1.2 \times 10^{-12, b}$ \\
\hline ethyne & $\left(\mathrm{C}_{2} \mathrm{H}_{2}\right)$ & 1 pptv & $0.9 \%$ & $9.0 \times 10^{-12, c}$ \\
\hline carbon monoxide & $(\mathrm{CO})$ & $3 \mathrm{ppbv}$ & $0.7 \mathrm{ppbv}$ & $2.1 \times 10^{-13, c}$ \\
\hline
\end{tabular}

a NMHC data from Baker et al. (2010); CO data from Brenninkmeijer et al. (2007).

b Atkinson and Arey (2003).

c Atkinson et al. (1997).

KNMI TRAJKS model is used to calculate 5 day back trajectories along the flight track at $3 \mathrm{~min}$ intervals (Scheele et al., 1996). Additionally, for each whole air sample 8-day backwards trajectories are calculated for the sampling interval.

Results of measurements of greenhouse gases from the CARIBIC TRAC samples have been presented in a previous work, along with a detailed description of the meteorological situation during CARIBIC FRA-MAA flights in 2008 (Schuck et al., 2010). For brevity we present a shortened meteorological overview here, and for comparability we apply the same classification of monsoon samples as used for discussion of greenhouse gas trends. The analysis was restricted to tropospheric samples collected south of $40^{\circ} \mathrm{N}$, which showed no stratospheric influence. Samples omitted on this basis were characterized as having been collected in air masses with a potential vorticity greater than 1.3 PVU ( $\left.1 \mathrm{PVU}=10^{-6} \mathrm{~km}^{2} \mathrm{~kg}^{-1} \mathrm{~s}^{-1}\right)$, which also had elevated $\mathrm{O}_{3}$ concentrations coupled with low levels of other trace gases (e.g. $\mathrm{SF}_{6}, \mathrm{~N}_{2} \mathrm{O}$ ). In total, 134 of the 153 samples collected in this region were considered for analysis; the 19 excluded samples all showed evidence of direct stratospheric influence.

Horizontal wind speeds at flight level (250-200 hPa pressure levels) recorded during flight were used to classify the monthly sampling periods as either monsoon (summer), transition (spring/fall) or winter periods (Schuck et al., 2010). Monsoon months (June-September) were characterized by easterly flow south of $\sim 25^{\circ} \mathrm{N}$, having maximum zonal wind speeds of $30 \mathrm{~m} \mathrm{~s}^{-1}$ and westerly flow north of $25^{\circ} \mathrm{N}$, with maximum winds speeds around $35 \mathrm{~m} \mathrm{~s}^{-1}$. Transition months (April, May and October) lack easterly flow and have lower wind speeds than during monsoon months; winter months (November and December) also have only westerly flow, but wind speeds are much higher than during summer, reaching maxima of $60 \mathrm{~m} \mathrm{~s}^{-1}$. During the monsoon season the CARIBIC aircraft passed through the monsoon anticyclone, exemplified by the flight on 13 August, for which wind fields at flight level $(\sim 250 \mathrm{hPa})$ are shown in Fig. 2a. Features present in the wind fields are the anticyclonic circulation attributed to the monsoon, with westerly flow in the north and easterly flow in the south.

\section{Results and discussion}

\subsection{NMHC in monsoon outflow}

Seasonal variations in NMHC mixing ratios are predominantly controlled by their reaction with the hydroxyl radical $(\mathrm{OH})$, leading to maxima in winter, when $\mathrm{OH}$ production is low, and minima in summer when $\mathrm{OH}$ levels peak, with lower amplitudes near the equator and in the tropics than farther north (or south). Contrary to the typical seasonal pattern, mean NMHC mixing ratios in the upper troposphere over South Asia are elevated during the summer (June-September) relative to spring and fall (April/May and October) (Fig. 3). These enhancements are attributed to increased transport to the UT due to stronger convective lofting during the monsoon period. Also shown are the seasonal profiles of the sum of the NMHCs ( $\Sigma$ NMHC, ppbC) and the fraction that is composed of more reactive NMHCs ( $\tau<10$ days), which is effectively the non-ethane fraction. The $\Sigma$ NMHC calculated is the sum of all compounds measured above the detection limit in the sample under consideration $\left(\mathrm{C}_{2}-\mathrm{C}_{8}\right.$ alkanes, ethyne, benzene, toluene, ethylbenzene, xylenes). The high $\Sigma$ NMHC during summer reinforces the trends observed for the individual species, while the enhanced fraction of reactive NMHCs, indicating less photochemical processing and therefore shorter transit times, highlights the contribution of younger air parcels.

Enhancements in NMHCs from June through September relative to the May/October average were calculated 

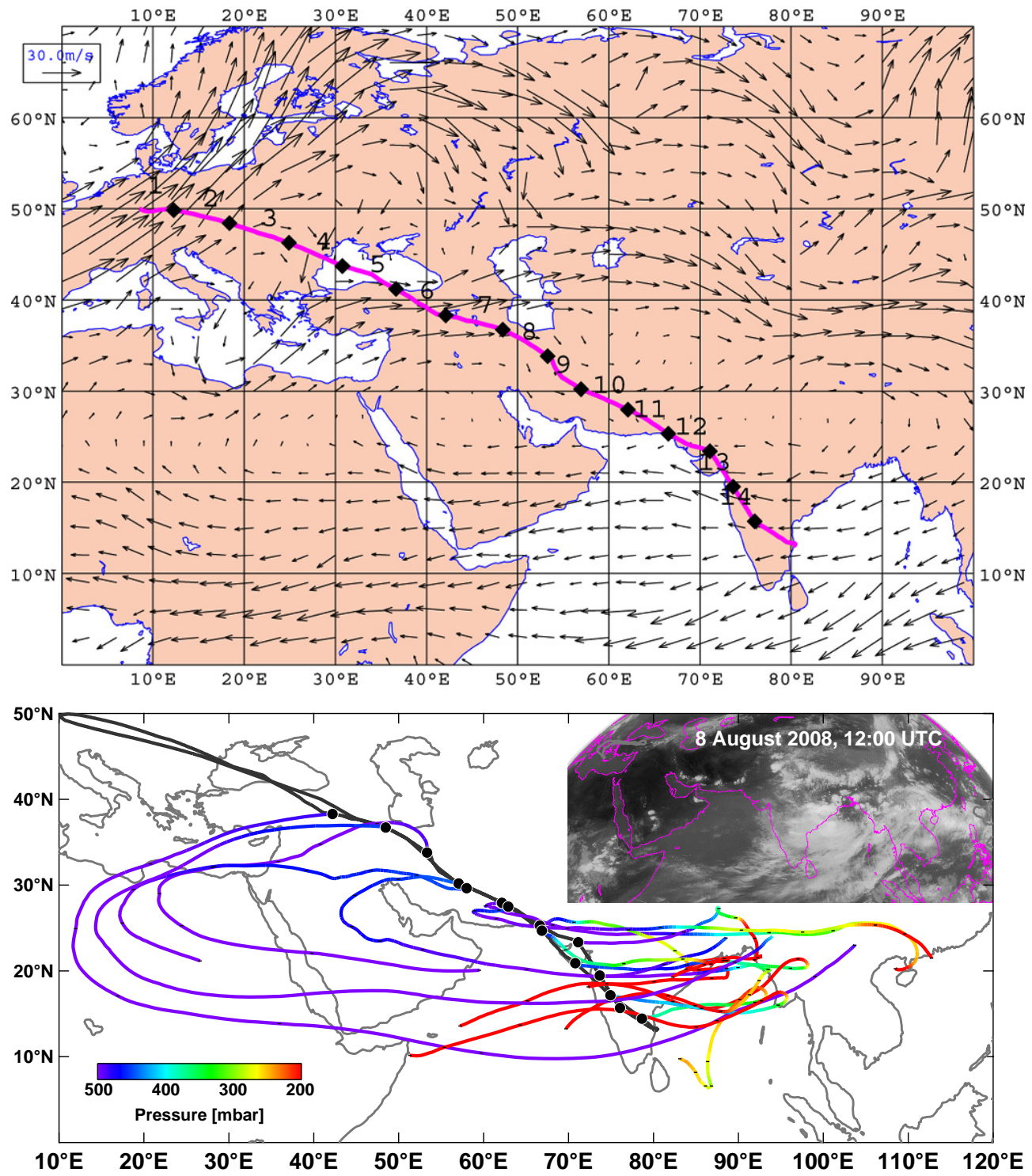

Fig. 2. (a) Wind field at $250 \mathrm{hPa}$ on 13 August 2008 for a flight from FRA to MAA. Direction is indicated by the arrows, which increase in size with wind speeds. The solid line is the flight path and markers denote whole air sampling locations. (b) Backward trajectories for the air samples collected within the monsoon circulation during the August 2008 flight. Markers along the trajectories indicate $24 \mathrm{~h}$ periods. Inset is a satellite image of cloud cover over the region at 12:00 UTC on 8 August 2008, 5 days prior to the flight (SSEC, http://www.ssec.wisc.edu/).

(Table 2) and, with the exception of ethane in September, summertime mixing ratios were enhanced relative to the months preceding and following the monsoon, sometimes by a factor of 2 or more. The largest relative enhancements were observed for benzene, ethyne and i-butane. Benzene and ethyne are associated with combustion and, more specifically, these compounds have a strong association with biomass and biofuel burning that the other NMHCs lack. Biomass/biofuel burning has previously been found to be a significant source of NMHCs in this region (de Gouw et al., 2001; Lelieveld et al., 2001) and enhancements in benzene and ethyne indicate the influence of this source. The burning of biofuels is estimated to account for about $50 \%$ of energy use in India, and is mostly attributed to energy use outside of large urban centers, where fossil fuels are dominant (Ohara et al., 2007; Streets et al., 2003). Model results from the 1999 INDOEX campaign show that between 60 and $90 \%$ of $\mathrm{CO}$ can be attributed to biomass/biofuel burning, and that the burning of biofuels in particular represents a large fraction of total biomass burning (Lelieveld et al., 2001). As open biomass burning (i.e. forest/wild fires) is expected to be low during the rainy monsoon season, the burning of household biofuels is believed to be dominant during this period. The reason for the relatively large enhancements in i-butane is not 

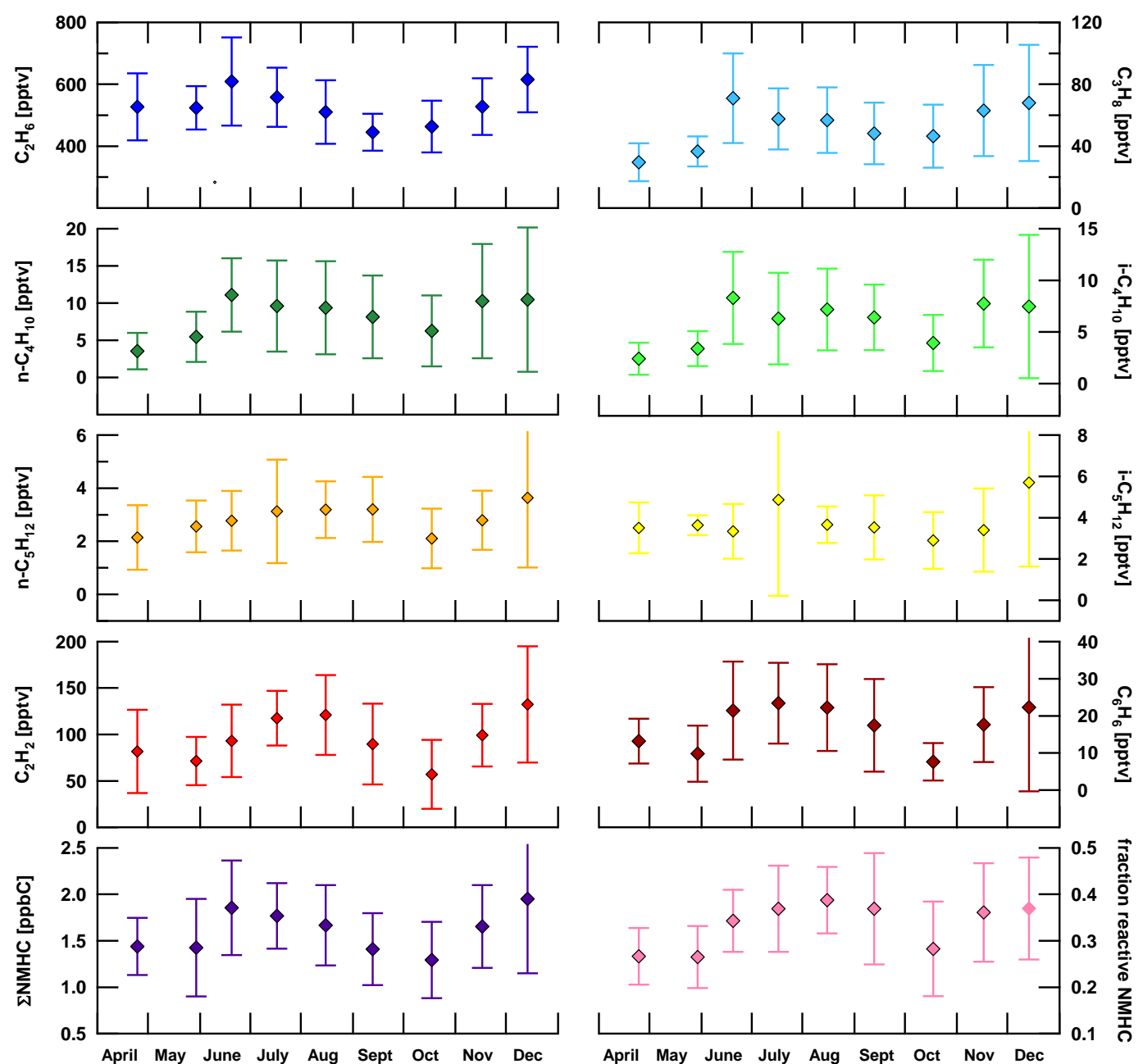

Fig. 3. Monthly mean mixing ratios of NMHCs from samples collected between 15 and $40^{\circ} \mathrm{N}$ along the FRA-MAA route. Error bars denote one standard deviation of the mean.

immediately clear. Sources of i-butane are strongly linked to those of other alkanes, particularly n-butane, with which it shares the same sources, namely related to the use of various fossil fuels.

Latitudinal profiles of NMHCs during the monsoon period reveal a distinct "monsoon pattern", where maximum mixing ratios are observed between 22 and $28^{\circ} \mathrm{N}$, with segments to the north and south having lower mixing ratios (Fig. 4). This is consistent with backwards trajectory analysis, which shows the samples with the highest concentrations to have been most recently influenced by air from the continental boundary layer, as opposed to the marine boundary layer or air masses without recent low level contact (van Velthoven, 2009). As expected, the latitudinal profile of $\Sigma$ NMHC tracks that of individual compounds. However, the reactive fraction is larger in the south than in the north, remaining fairly constant until $\sim 26^{\circ} \mathrm{N}$, where it then drops off, and decreases until $40^{\circ} \mathrm{N}$. This difference between north and south is in- dicative of the relative processing of the air parcels, pointing to freshly polluted air parcels in the easterly flow of the southwest region of the anticyclone and more processed air parcels in the westerly flow of the northwestern region of the anticyclone. A more detailed discussion of the degree of photochemical processing is presented in Sect. 3.3, but we point out here the qualitative information provided by NMHC composition.

\subsection{NMHC-CO relationships and source identification}

Concentration ratios between NMHCs and $\mathrm{CO}$ $(\triangle \mathrm{NMHC} / \triangle \mathrm{CO})$, as well as between different NMHCs, are frequently employed for identification of sources, as many source types have specific ratios. These relationships were determined for CARIBIC samples from the slope of the linear least squares fit to scatter plots between individual NMHCs and the integrated $\mathrm{CO}$ value for the sampling period 
Table 2. Enhancements of NMHC during summer months relative to May/October. Differences are given in pptv and represent the difference between monthly means; enhancement is shown in parentheses.

\begin{tabular}{lrrrr}
\hline & June & July & August & September \\
\hline Ethane & $115.4(23 \%)$ & $64.5(13 \%)$ & $16.3(3 \%)$ & $-48.6(-10 \%)$ \\
Propane & $29.4(71 \%)$ & $16.1(39 \%)$ & $15.3(37 \%)$ & $6.6(16 \%)$ \\
i-Butane & $4.6(127 \%)$ & $2.6(72 \%)$ & $3.5(96 \%)$ & $2.8(75 \%)$ \\
n-Butane & $5.2(89 \%)$ & $3.7(64 \%)$ & $3.5(60 \%)$ & $2.3(39 \%)$ \\
i-Pentane & $0.1(2 \%)$ & $1.6(49 \%)$ & $0.4(12 \%)$ & $0.3(8 \%)$ \\
n-Pentane & $0.4(19 \%)$ & $0.8(34 \%)$ & $0.9(37 \%)$ & $0.9(37 \%)$ \\
Ethyne & $28.9(45 \%)$ & $53.3(83 \%)$ & $56.8(89 \%)$ & $25.4(40 \%)$ \\
Benzene & $12.7(145 \%)$ & $14.7(168 \%)$ & $13.5(154 \%)$ & $8.7(99 \%)$ \\
\hline
\end{tabular}

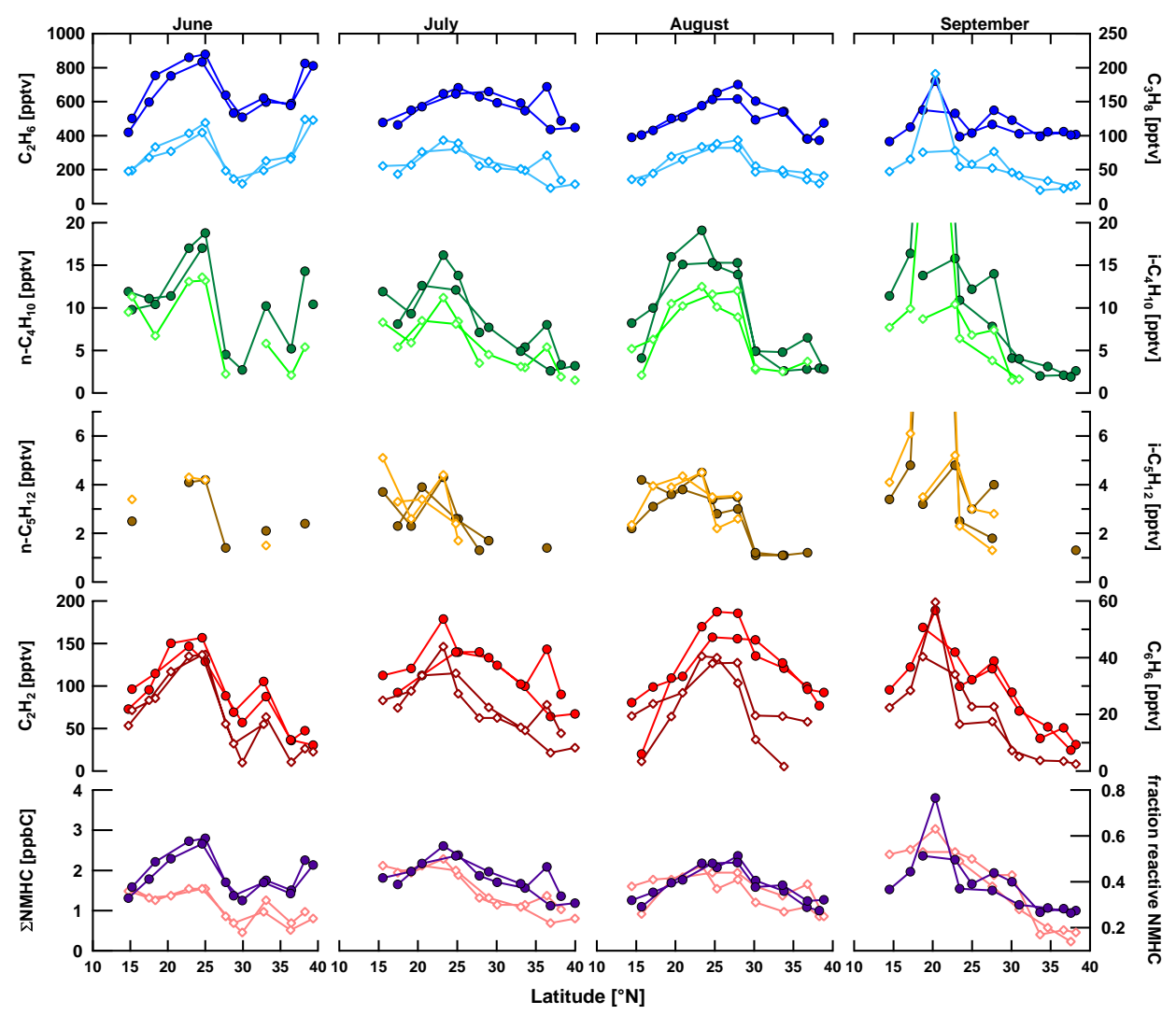

Fig. 4. Latitudinal profiles of NMHCs measured during June-August flights between FRA and MAA. Filled circles represent the compounds on the left axis, open diamonds to the compounds on the right axis. For the sample in September collected at $\sim 19^{\circ} \mathrm{N}$ for which n-butane, i-butane, n-pentane and i-pentane are off-scale, the corresponding mixing ratios are 62 pptv, 44 pptv, 25 pptv and 32 pptv, respectively.

derived from in situ measurements (Fig. 5). To minimize the influence of different degrees of photochemical processing of the air parcels, NMHC-CO and NMHC-NMHC relationships were determined only from those samples $(n=15)$ collected in July and August having backwards trajectories indicating low level (pressure $>600 \mathrm{hPa}$ ) contact within the previous 3-5 days. Trajectories from the August flight are shown in Fig. 2b, along with a satellite image of cloud cover (indicating areas of convection) on 8 August 2008, 5 days prior to the CARIBIC flight. July and August were chosen as they represent the point in time when the monsoon was fully developed and are expected to have the most similar meteorological, and also photochemical, conditions. We further emphasize that these ratios are not expected to represent actual emission ratios, but remain useful as tools for assessing sources influencing air mass composition. 

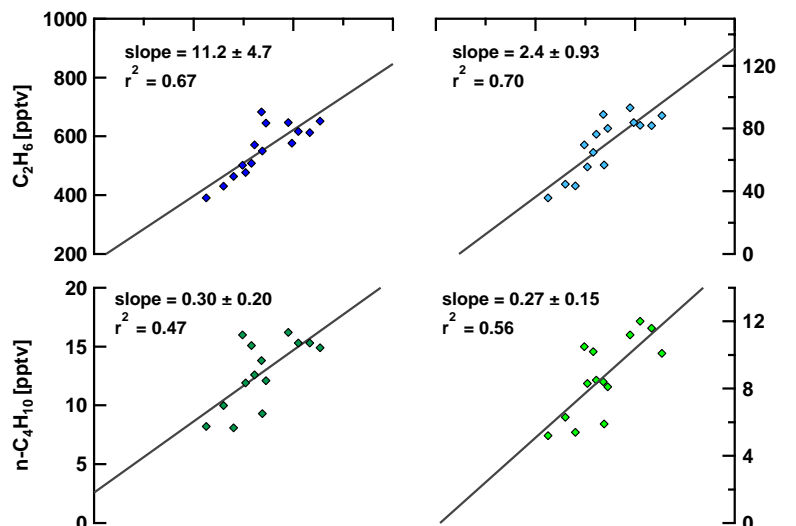

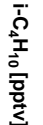
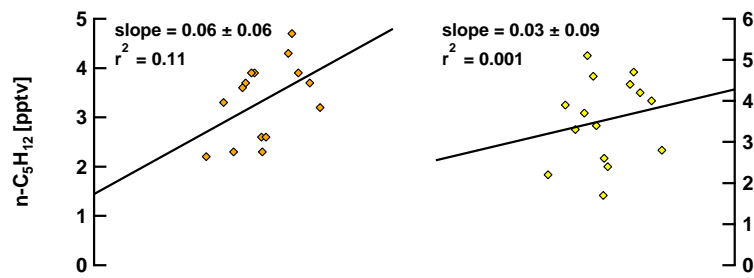

$\frac{1}{0}$
$\frac{1}{N}$
$\frac{7}{3}$
$\frac{7}{3}$
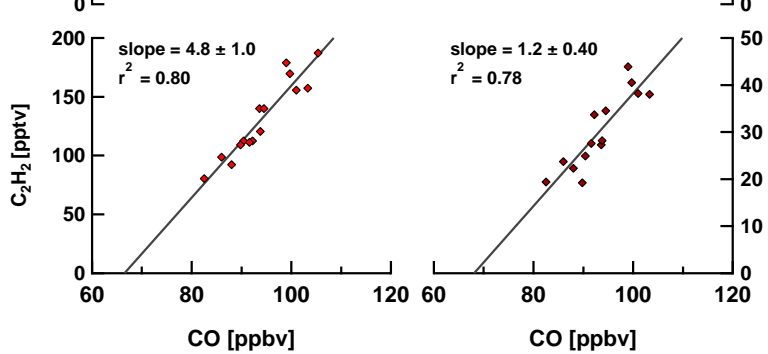

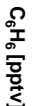

Fig. 5. Correlation plots of observed mixing ratios of NMHCs with $\mathrm{CO}$ in fresh (3-5 day transport times; see text) monsoon outflow during July and August. Slopes of the correlation have units of pptv $\mathrm{NMHC} / \mathrm{ppbv} \mathrm{CO}$ and the uncertainty represents the $95 \%$ confidence interval of the slope.

With the exception of the pentanes, the NMHCs considered exhibit statistically significant correlations with CO. Benzene and ethyne, which share many of the same (combustion) sources with $\mathrm{CO}$, are well correlated with $\mathrm{CO}\left(r^{2}>\right.$ 0.75). The $\mathrm{C}_{2}-\mathrm{C}_{4}$ alkanes, which share fewer sources with $\mathrm{CO}$ than benzene and ethyne, are also correlated with $\mathrm{CO}$, which can be attributed to the co-location of their sources and the well-mixed nature of the air parcels probed. The lack of correlation exhibited by the pentanes is most likely explained by their short lifetimes, which result in them having been rapidly removed from these air parcels, giving mixing ratios close to the detection limit.

Concentration ratios between $\mathrm{CO}$ and ethane, propane, ethyne and benzene determined from CARIBIC samples were compared to source emission ratios for biomass burning (tropical forests) and biofuel burning (Andreae and Merlet, 2001), and to concentration ratios from urban samples collected in Ahmedabad, India in 2002 (Sahu and Lal, 2006a) (Table 3). Biomass and biofuel burning emissions are pre- sumed to be from suburban and rural areas and are expected to have little influence in urban areas. As the air parcels encountered by CARIBIC had spent the preceding 3-5 days in transport, ratios determined between NMHCs and $\mathrm{CO}$ are certain to be smaller than the actual emission ratios. Despite this, in the cases of ethane, propane and ethyne, observed CARIBIC ratios actually exceed the emission ratios determined for biomass burning and approach the higher emission ratios determined for biofuel burning. Compared to measurements from Ahmedabad, $\Delta$ ethane/ $\Delta \mathrm{CO}$, and $\Delta$ ethyne/ $\triangle \mathrm{CO}$ are higher than measured in urban air, although $\Delta$ propane/ $\Delta \mathrm{CO}$ is actually lower.

Using observed CARIBIC concentration ratios we estimate the initial emission ratios $\left(\mathrm{ER}_{0}\right)$ by applying an age correction to the observed values (Table 3 ). This aids not only in comparison to emission ratios, but also facilitates comparison between CARIBIC data and age corrected data from measurements of Indian outflow encountered in the troposphere during the INDOEX campaign (de Gouw et al., 2001) and monsoon outflow measured in the UT over the Mediterranean during MINOS (Scheeren et al., 2003), which had different transport times and conditions than during CARIBIC flights. Given the different regions of the atmosphere (lower troposphere vs. UT) and different times of year for these campaigns, comparison of observed ratios is not particularly valuable; comparison of age-corrected ratios attempts to reduce the influence of these factors by effectively comparing the air mass composition at emission. The age correction is based on the method used by de Gouw et al. (2001) and Scheeren et al. (2003) where the relationship between $\mathrm{ER}_{0}$ and the ratio determined from the measurements is given as:

$\mathrm{ER}_{0}=\mathrm{ER}_{t} e^{-\left(k_{B}-k_{A}\right)\langle[\mathrm{OH}]\rangle \Delta t}$

where $\mathrm{ER}_{t}$ is the ratio of compound $A$ to compound $B$ in the air parcel, $k_{A}$ and $k_{B}$ are the rates of reaction with $\mathrm{OH}$ of the two compounds (see Table 1), $\langle[\mathrm{OH}]\rangle$ is the average concentration of $\mathrm{OH}$ encountered by the air parcel during transit, and $\Delta \mathrm{t}$ is the transport time. We note that this method assumes that mixing with other air masses is negligible, which, even over the relatively short period of a few days, may not be the case. If the mixing was with cleaner, background air, the result of this mixing would be to reduce the emission ratios estimated here. Emission ratios were estimated from ratios determined from CARIBIC observations, with an estimated transport time of 4 days, which represents the average time since low level contact for the samples, according to the backwards trajectories (van Velthoven, 2009), and $\langle[\mathrm{OH}]\rangle$ of $2.48 \times 10^{6}$ molec $\mathrm{cm}^{-3}$ (Spivakovsky et al., 2000 ), which is the concentration of $\mathrm{OH}$ predicted at $20^{\circ} \mathrm{N}$ and $500 \mathrm{hPa}$ (estimated to have an uncertainty of $\pm 25 \%$ ), the average conditions attributed to the samples from their backwards trajectories.

The applied age correction resulted in an $\mathrm{ER}_{0}$ estimate from $\Delta$ ethyne/ $\Delta \mathrm{CO}$ that is very similar to biofuel burning and is far in excess of biomass burning or urban emission 
Table 3. Observed and age corrected ratios between select NMHC and CO for the current study (CARIBIC), compared to literature values. Observed refers to ratios determined from the measurements, Age corr. refers to values corrected for photochemical loss during transport (see text). Units are pptv ppbv ${ }^{-1}$.

\begin{tabular}{|c|c|c|c|c|c|c|c|c|c|}
\hline \multirow[t]{2}{*}{ Ratio } & \multirow[t]{2}{*}{$\begin{array}{l}\text { Biomass } \\
\text { Burning }^{\text {a }}\end{array}$} & \multirow[t]{2}{*}{$\begin{array}{c}\text { Biofuel } \\
\text { Burning }\end{array}$} & \multirow{2}{*}{$\begin{array}{c}\text { Indian urban } \\
(\text { Ahmedabad, } \\
\text { 2002) }\end{array}$} & \multicolumn{2}{|c|}{$\begin{array}{c}\text { Indian outflow } \\
\text { (INDOEX, 1999) }\end{array}$} & \multicolumn{2}{|c|}{$\begin{array}{l}\text { Monsoon Outflow } \\
(\text { MINOS, 2001) })^{\mathrm{d}}\end{array}$} & \multicolumn{2}{|c|}{$\begin{array}{c}\text { CARIBIC } \\
\text { (this study, 2008) }\end{array}$} \\
\hline & & & & Observed & Age Corr. & Observed & Age Corr. & Observed & Age Corr. \\
\hline Ethane/CO & 10.8 & 14.3 & 8.5 & 5.8 & 7.2 & & & 11.2 & 11.6 \\
\hline Propane/C & 0.9 & 4.1 & 9.1 & 0.4 & & & & 2.4 & 5.1 \\
\hline Ethyne/CO & 4.1 & 8.5 & 2.9 & 3.3 & 7.9 & 5.1 & 7.4 & 4.8 & 8.7 \\
\hline Benzene/CO & 1.3 & 4.4 & & 0.95 & 2.3 & 0.32 & 0.92 & 1.2 & 2.9 \\
\hline
\end{tabular}

a Andreae and Merlet (2001).

b Sahu et al. (2006a).

c de Gouw et al. (2001).

d Scheeren et al. (2003).

ratios (Table 3 ). The $\Delta$ ethyne/ $\Delta \mathrm{CO} \mathrm{ER}_{0}$ estimate also agrees well with $\mathrm{ER}_{0}$ estimates from INDOEX and MINOS. This indicates a dominant biofuel burning source for ethyne (and also for $\mathrm{CO}$ ) and is in agreement with previous findings for the region. The $\mathrm{ER}_{0}$ estimated for $\Delta$ benzene/ $\Delta \mathrm{CO}$ is lower than the biofuel burning emission ratio, but is still much higher than estimated for open biomass burning. Unfortunately, benzene measurements are not available for Ahmedabad, however, studies of other areas in Asia indicate a ratio from transport of about 1 pptv benzene/ppbv $\mathrm{CO}$ (Carmichael et al., 2003), which is much lower than the observed and age corrected ratios from CARIBIC measurements. That these are still far smaller than biofuel burning emission ratios indicates a larger transportation-related source of benzene than for either $\mathrm{CO}$ or ethyne.

While both ethane and propane have sources from the burning of biofuel, they also have significant sources from the use of fossil fuels, particularly LPG and natural gas, with which they are strongly associated. Estimates of $\mathrm{ER}_{0}$ for both compounds fall between biofuel burning and urban emission ratios, pointing to a potentially large contribution from fossil fuels. Additionally, $\Delta$ ethane/ $\Delta \mathrm{CO}$ is higher than observed in Indian outflow during the 1999 INDOEX campaign by nearly a factor of 2 . While it is possible that the enhancement in ethane relative to $\mathrm{CO}$ is the result of seasonal variations in emissions or of probing air parcels having different source regions within India during the two campaigns, it could also be considered the result of an increase in the use of LPG and natural gas as household fuels in the intervening 9 years. Fuel consumption data for India show the use of fuels other than coal and biofuel as household fuels to have more than doubled between 1980 and 2003, from $4.4 \%$ to $11.1 \%$ of total household fuel consumption (Ohara et al., 2007). Furthermore, increases in emissions of non-methane volatile organic compounds from India were predicted to outpace those of CO by a factor of 3 between 2000 and 2010 by Ohara et al. (2007), attributable to the increased use of fossil fuels in general.
Lastly, in an effort to better understand the large seasonal enhancement in i-butane, we also determined the ratio between i-butane and n-butane in monsoon outflow (Fig. 6a). Emissions of the butane isomers are strongly coupled, and while they are emitted by biomass and biofuel burning, they are largely attributed to the use of fossil fuels, not only natural gas and LPG, but also gasoline. The rates of reaction with $\mathrm{OH}\left(k_{\mathrm{OH}}\right)$ for these compounds are nearly equal, and if $\mathrm{OH}$ is the only sink, the ratio between the two isomers is expected to change little with photochemical processing during transport, meaning that the ratio determined from CARIBIC samples is effectively the emission ratio. The ratio of $0.77 \pm 0.07 \mathrm{pptv}^{\mathrm{pptv}}{ }^{-1}$ i-butane/n-butane found in recent monsoon outflow is higher than determined from samples collected outside of the monsoon region and also during other seasons, for which it was $0.55 \pm 0.05$ (Fig. 6b). This is indicative of a relatively unique source signature for the region, and also potentially provides an explanation for the increased enhancement of i-butane mixing ratios compared to other alkanes in monsoon outflow. Additionally, the invariability of the ratio, even in the north where transport times are longer, provides qualitative evidence for the minimal influence of dilution on monsoon outflow, indicating that air parcels transported in the monsoon circulation remain considerably isolated. The observed ratio is also higher than reported literature values of 0.33 for biofuel burning (Andreae and Merlet, 2001) and of 0.37-0.55 for urban measurements (Bottenheim et al., 1997; Derwent et al., 2000; Parrish et al., 1998), and is approaching values of $\sim 1.1$ reported for areas strongly influenced by the petrochemical industry (Jobson et al., 2004). The ratio of i-butane/n-butane clearly shows the influence of urban/industrial sources and also corroborates the additional fossil-fuel sources of ethane and propane. 
a)

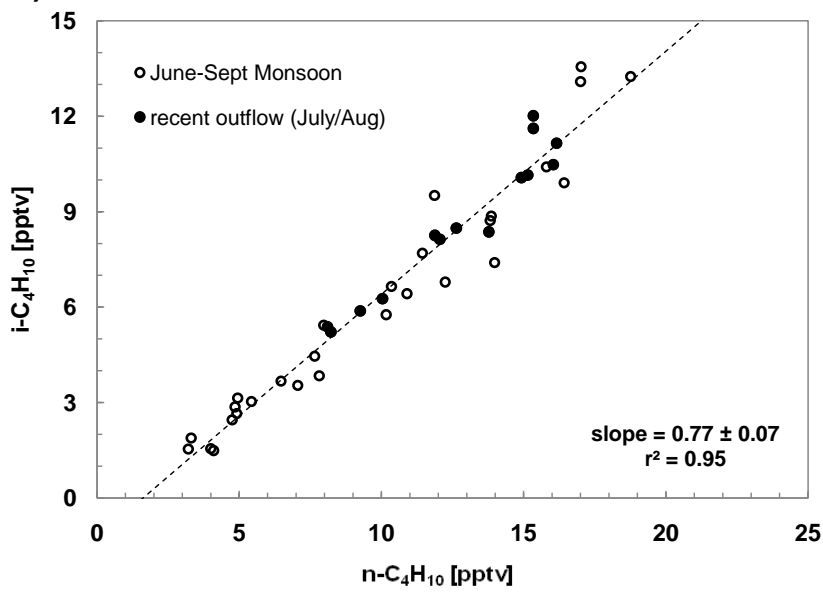

b)

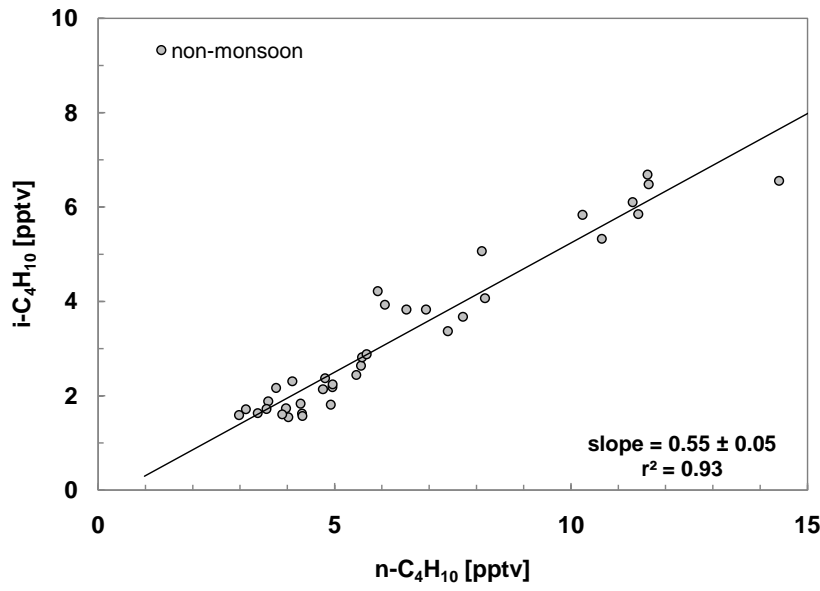

Fig. 6. Correlation plots of i-butane vs. n-butane from (a) samples collected in monsoon outflow and (b) samples collected outside of the monsoon season (April-May and October-December) on the FRA-MAA route. The slope in (a) is for the recent outflow only. The uncertainties represent the $95 \%$ confidence intervals of the slopes.

\subsection{Estimates of photochemical ages and processing}

In Sect. 3.1 we noted that the latitudinal distribution of the fraction of shorter-lived NMHCs provides qualitative information about the relative processing of the air parcels in the different regions of the monsoon anticyclone probed by the CARIBIC aircraft. In this section we expand our analysis of photochemical processing of monsoon outflow through the estimation of photochemical ages. In general, the ratio between two NMHCs having different chemical lifetimes is used to determine transport times, as this relationship is dependent on the degree of photochemical processing. The utility of using NMHC "photochemical clocks" has been examined by a number of investigators, and the framework for examination of the $\mathrm{C}_{2}-\mathrm{C}_{5}$ alkanes to study photochemical aging has been particularly well characterized (Jobson et al., 1998; Parrish et al., 1998, 2007).
A common method for examining the photochemical processing of an air parcel is to examine the ratio between two hydrocarbons, $A$ and $B$, having different rates of reaction with $\mathrm{OH}, k_{A}$ and $k_{b}$ :

$\Delta t=-\frac{1}{\left(k_{A}-k_{b}\right)\langle[\mathrm{OH}]\rangle} \ln \left(\frac{[A]_{t} /[B]_{t}}{[A]_{0} /[B]_{0}}\right)$

where $[A]_{t} /[B]_{t}$ is the ratio between two NMHCs measured in the air parcel, and $[A]_{0} /[B]_{0}$ is their emission ratio at the source; in effect, this equation is a rearrangement of Eq. (1) to solve for $\Delta t$. This method removes the reliance on knowing the absolute mixing ratios of the NMHCs at the source, and also accounts to some extent for dilution, which is expected to act equally on both NMHCs, thereby having a smaller effect on the ratio than the absolute concentrations.

This method assumes that background mixing ratios for the two hydrocarbons are negligible relative to their concentrations in the air parcel; this assumption is reasonable for very short-lived compounds, but does not necessarily hold true for longer-lived compounds (e.g. ethane) which can have large background concentrations. To obtain a qualitative estimate of the applicability of the photochemical ages derived from Eq. (2), Parrish et al. (1992) suggest the comparison of the estimates derived from two different NMHC ratios, calculated from the measurements of three different NMHCs, $A, B$ and $C$. If only reaction with $\mathrm{OH}$ is acting on the ratios in the air parcel, the two estimates will be related by the following linear expression:

$$
\begin{aligned}
\ln \left(\frac{[A]_{t}}{[B]_{t}}\right) & =\frac{\left(k_{A}-k_{B}\right)}{\left(k_{C}-k_{B}\right)} \ln \left(\frac{[C]_{t}}{[B]_{t}}\right) \\
& +\left[\ln \left(\frac{[A]_{0}}{[B]_{0}}\right)-\frac{\left(k_{A}-k_{B}\right)}{\left(k_{C}-k_{B}\right)} \ln \left(\frac{[C]_{0}}{[B]_{0}}\right)\right]
\end{aligned}
$$

This relationship eliminates the dependence on knowing $\langle[\mathrm{OH}]\rangle$ or $\Delta t$, and predicts a slope that is dependent only on the values of $k_{\mathrm{OH}}$ for the different NMHCs. To reduce autocorrelation effects associated with having the same compound as the denominator for the two ratios, it is suggested that the least reactive NMHC (typically ethane) be used as the denominator (Parrish et al., 1992).

Using the mixing ratios of ethane, propane and n-butane, Eq. (3) was applied to all samples collected in the monsoon anticyclone during July and August (Fig. 7). We applied emission ratios of 0.29 and 0.15 for propane/ethane and n-butane/ethane, respectively, estimated from ground-based measurements of these compounds at rural/suburban sites in the region, where a mixture of urban and biofuel burning sources influence NMHC composition (Lal et al., 2008; Sahu and Lal, 2006b). The slope of $2.35 \pm 0.29$ is slightly smaller than those predicted for a temperature range of $220-310 \mathrm{~K}$, where the slopes fall in the range of 2.4 to 3.0 , although it is close enough that we consider the photochemical estimates to be valid and relatively free of the influence of mixing with other air parcels. Interestingly, those samples falling furthest 


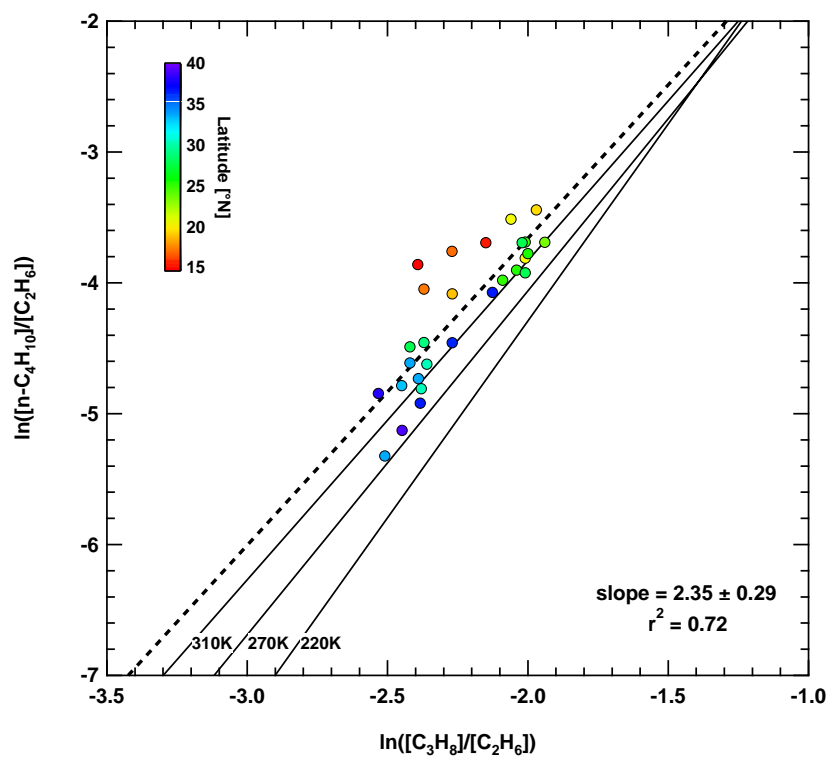

Fig. 7. Correlation of the natural logarithms of n-butane/ethane and propane/ethane from all samples collected in monsoon outflow during July and August. Points are color-coded by sampling location latitude. The dashed line represents the linear fit to the data, while the solid lines represent, relationships predicted for purely chemical loss by reaction with $\mathrm{OH}$ at $310 \mathrm{~K}, 270 \mathrm{~K}$ and $220 \mathrm{~K}$ (slopes from 2.44 to 3.01 ). The uncertainty of the slope denotes the $95 \%$ confidence interval.

from the kinetic slope were those collected furthest south, potentially indicating a larger input of air from the marine boundary layer, which is relatively depleted in propane and n-butane compared to ethane.

To estimate the ages of the air parcels encountered in monsoon outflow we applied Eq. (2) to CARIBIC data from July and August using the ratios of propane and $n$ butane to ethane in conjunction with the estimated $\langle[\mathrm{OH}]\rangle$ of $2.48 \times 10^{6}$ molec cm $^{-3}$ from Spivakovsky et al. (2000) and emission ratios of 0.29 and 0.15 for propane/ethane and $n-$ butane/ethane, respectively, as used above. Photochemical ages determined for CARIBIC samples ranged from 3 to 8 days and estimates from the two ratios are in fairly good agreement, although n-butane/ethane ages are slightly lower than those determined from propane/ethane, with the poorest agreement for samples collected farthest south (Fig. 8a). Ages derived from NMHCs also show a general increasing trend with sampling latitude.

When compared to age estimates derived from backwards trajectories for samples collected in the southern region of the anticyclone, NMHC derived photochemical ages appear reasonable and are in fairly good agreement, with the exception of 3 samples collected farthest south (Fig. 9). However, in the north, where many of the 8-day backwards trajectories show no low level contact and often do not extend back to the primary convective regions over South Asia (see Fig. 2b),
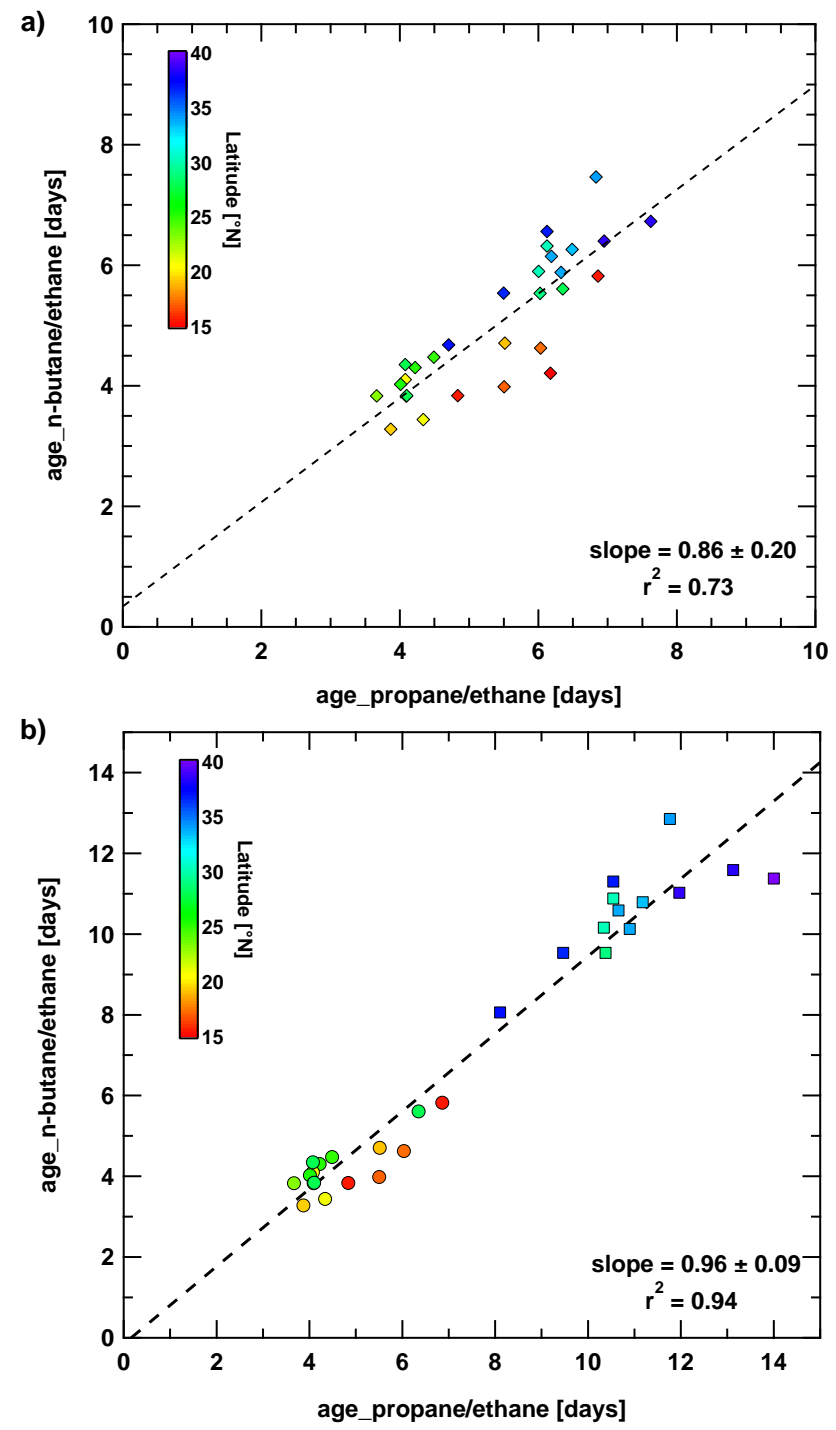

Fig. 8. Comparison between ages determined from n-butane/ethane and propane/ethane (a) assuming the same $\langle[\mathrm{OH}]\rangle$ in both the north and the south and (b) using different $\langle[\mathrm{OH}]\rangle$ for northern (squares) and southern (circles) regimes. The dashed line represents the linear fit to the data, with uncertainties representing the $95 \%$ confidence interval. Points are color-coded by sampling location latitude.

age estimates from NMHCs of 6-8 days are clearly unrealistic. Even if information provided by the backward trajectories is ignored, these times seem short when considering the long transport distances and prevailing wind speeds. As mentioned previously, monsoon samples were collected in two different regimes, having two very different residence times within the larger UT/LS monsoon circulation. It is therefore unsurprising that samples in the north, which had been in transit longer, with the bulk of their time spent at high altitude/low pressure in the UT/LS, would require different treatment than samples having spent only a few days at high altitude. One would expect that the $\langle[\mathrm{OH}]\rangle$ encountered 


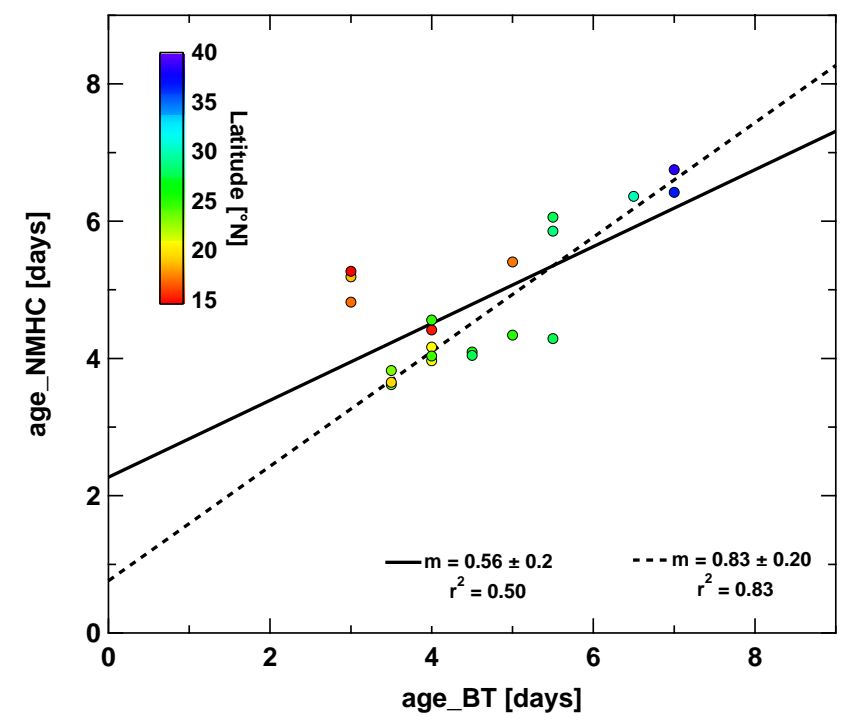

Fig. 9. Comparison of ages determined from NMHC in CARIBIC samples (age_NMHC, which is the average age determined from the ratios of propane and n-butane to ethane) and the age estimated from backwards trajectories (age_BT) for those samples where backwards trajectories showed low level contact within the preceding 8 days. The solid black line is the linear fit to all data; the dashed black line is the fit to the data if the 3 outliers are excluded (see text). Points are color-coded by sampling location latitude.

by these air parcels would be different from, and presumably smaller than, that encountered by more recent outflow, which was used for the preceding estimations of age. In light of this, and barring the use of sophisticated modeling techniques (which are beyond the scope of this work), a simplistic approach is to treat the two regimes separately, as having different $\langle[\mathrm{OH}]\rangle$ for estimations of photochemical age. Using the conditions common to these samples we instead apply an estimated $\langle[\mathrm{OH}]\rangle$ of $1.44 \times 10^{6}$ molec cm $\mathrm{cm}^{-3}$ (Spivakovsky et al., 2000) for the samples in the northern regime, and this results in much more realistic estimations of the photochemical ages of the air parcels between 9 and 12 days (Fig. 8b). Ultimately we see a photochemical aging pattern where the air masses in the south have had relatively short photochemical processing times and still contain a large fraction of more reactive, shorter-lived NMHCs, and these are separated from air parcels in the north by transport times of 3 to 8 days, during which time a substantial fraction of the remaining reactive NMHCs are removed.

It is important to note that there are large uncertainties associated with estimates of photochemical processing, primarily dependent on the use of model-derived $\mathrm{OH}$ and emission ratio estimates from ground-based studies. Uncertainties in $[\mathrm{OH}]$ of $\pm 25 \%$ correspond to transport times that are underestimated by $33 \%$ in the case of $[\mathrm{OH}]$ being lower than the estimate, and a $20 \%$ overestimate in transport times if [OH] is higher. As previously mentioned, NMHC data for this re-

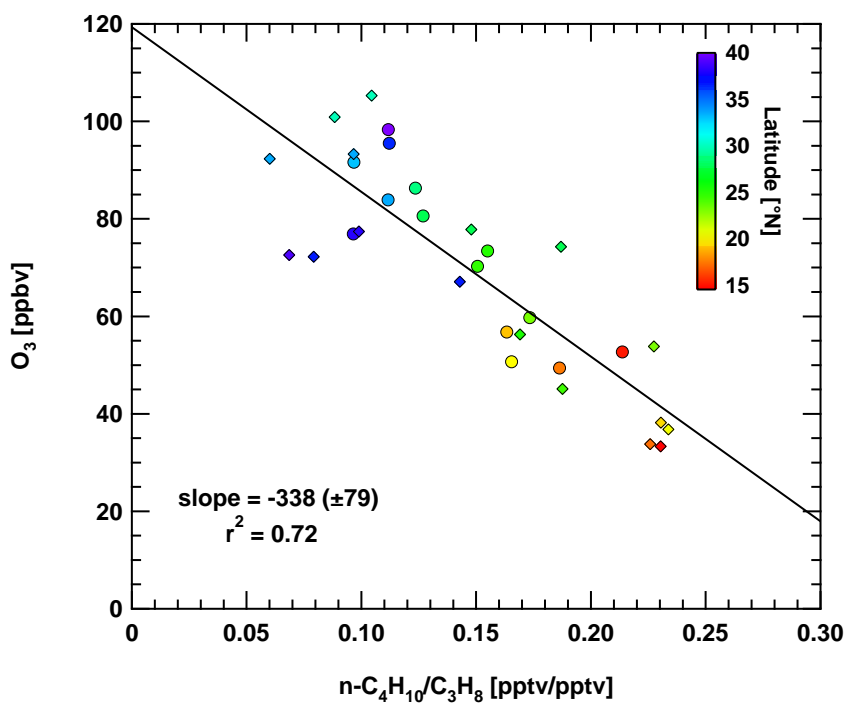

Fig. 10. Relationship between $\mathrm{O}_{3}$ and n-butane/propane within the monsoon region during July (circles) and August (diamonds). The solid line represents the linear fit the data (for both months) and the uncertainty of the slope represents the $95 \%$ confidence interval. Points are color coded by sampling location latitude.

gion are limited, which accordingly limit the certainty in the emissions ratios used in the transport time estimates. Smaller actual emission ratios would mean that predicted $\Delta t$ values are too high, while larger emission ratios would give $\Delta t$ values that are too low. For these reasons we estimate a 50\% uncertainty for the photochemical ages predicted here, and emphasize the qualitative aspect of the estimates showing increased photochemical processing in more northern, westerly flow, compared to the younger, less processed air masses in the easterly flow to the south.

The degree of processing of the air parcels is an indication of their tendency to form ozone, with less processed parcels having a greater potential for ozone formation. In the monsoon anticyclone, CARIBIC ozone mixing ratios during July and August increased with latitude, with a steeper increase upon entering the westerly flow in the north (described in detail in Schuck et al., 2010). Data from July and August show that, in general, ozone within the anticyclone tends to increase as the ratio between n-butane and propane decreases (Fig. 10). The ratio between the two NMHCs is used to represent the degree of photochemical processing of the NMHCs, and hence of the air parcel, and becomes smaller with increased ozone concentrations, indicating that the air parcel has a photochemical tendency to form ozone (Parrish et al., 1992, 2004). This relationship is stronger in the south than in the north, where the relationship becomes less clearly ozone producing. It is possible that this is a result of the air parcels no longer being ozone forming, or having a reduced tendency to form ozone, but this is difficult to say given the higher latitude at which the samples were collected. At higher latitudes 
the possibility for stratospheric intrusion increases, therefore, it is not possible for us to determine whether or not this is the result of the air parcels' reduced tendency for ozone formation, or to enhanced ozone levels due to stratospheric influence.

\section{Conclusions}

During a series of monthly research flights between Germany and India in 2008 the CARIBIC aircraft was able to conduct measurements within the Asian summer monsoon circulation and to assess the composition of outflow from over India and the Bay of Bengal, in which enhancements in many trace gases were observed. These enhancements were most likely the result of the rapid convection of boundary layer air to the UT/LS during the monsoon season, and among those compounds enhanced were the NMHCs. Of the NMHCs, ethyne and benzene, both of which have primarily combustion sources, had the largest enhancements, with JuneSeptember means that were between $40 \%$ and $168 \%$ higher than mean mixing ratios in April/May and October. Concentration ratios between these compounds and the $\mathrm{C}_{2}-\mathrm{C}_{5}$ alkanes and $\mathrm{CO}$ were determined from correlation plots, and these were then compared to various emission ratios to identify sources influencing composition. Estimates of $\mathrm{ER}_{0}$ from concentration ratios of $\Delta$ ethyne/ $\Delta \mathrm{CO}$ pointed to a dominant biofuel burning source for ethyne, while the $\Delta$ benzene/ $\Delta \mathrm{CO}$ ratio seemed to be the result of a combination of biofuel burning and transportation-related emissions. Comparison between these ratios and those from observations during INDOEX (representing Indian outflow) and MINOS (monsoon outflow) showed them to be similar during all three campaigns, suggesting no substantial changes to contributing sources over the nearly 10 years between CARIBIC and the previous campaigns.

Conversely, $\Delta$ ethane $/ \Delta C O$ and $\Delta$ propane $/ \Delta C O$ from CARIBIC measurements fell between biofuel burning emission ratios and ratios from measurements in Ahmedabad, India, indicating strong urban/industrial sources of these compounds in addition to the burning of biofuel. This is presumed to be mostly from the use of natural gas and LPG, and appears to be more significant as a source of propane than of ethane. The influence of urban/industrial emissions on the air parcels is further supported by the $\mathrm{i}$-butane/n-butane ratio of $0.77 \pm 0.07$ pptv pptv $^{-1}$, which is much higher than literature values for biofuel burning and is approaching those observed in areas influenced by emissions from the petrochemical industry. Comparison to measurements from the 1999 INDOEX campaign shows ethane and propane to be much more enhanced relative to $\mathrm{CO}$ during the 2008 CARIBIC flights. We consider this to be an indication of an increase in the use of fossil fuels in general, and of LPG and natural gas, specifically, during the near decade between the two studies. This finding is unsurprising in light of the recent increase of fossil fuel use in India, as well as projections for the near future.

The fraction of shorter-lived, reactive NMHCs showed that air masses in the westerly flow in the northern portion of the monsoon anticyclone were much more photochemically processed than air masses in the easterly flow to the south. Using NMHC "photochemical clocks" with conditions specific to the different regions gave age estimates between 3 and 6 days in the south, and between 9 and 12 days in the north. Despite an additional 3 to 9 days processing time, levels of NMHCs in the northern portion of the monsoon are still enhanced relative to levels at the same latitudes in other seasons. One of the chief concerns of monsoon outflow is its ability to transport reactive species to the upper troposphere in downwind regions, particularly to the Arabian Peninsula and the Mediterranean to the west, where they can participate in the formation of pollutant ozone. It is clear from CARIBIC observations that air masses in the southwestern region of the monsoon anticyclone have large enhancements of NMHCs to act as ozone precursors, and it is this region that was found to be the source region for westward transport. However, it should also be noted that even after spending a number of days being transported to the north and then eastwards, enhancements in NMHC still exist, and can potentially be added to East Asian outflow and contribute to trans-Pacific transport of pollutants.

As of yet, data from CARIBIC flights represent the only in situ measurements of atmospheric NMHC composition in the UT/LS within the Asian summer monsoon anti-cyclone. Additionally, CARIBIC results add to the limited number of measurements of trace gases from India, particularly for the NMHCs. While our data hint at changing sources of NMHCs as a likely consequence of the adoption of new fuels, increasing vehicular traffic and growing urban/industrial emissions, this result is not definitive and further investigation is needed to understand emissions from this dynamic region. Further growth and industrialization are expected to lead to increased emissions of atmospheric pollutants in general, and the monsoon provides an effective pathway for transport of these pollutants to other regions and possibly also into the stratosphere.

Acknowledgements. We wish to thank all CARIBIC partners as well as Lufthansa, especially T. Dauer and A. Waibel, Lufthansa Technik and Fraport for their ongoing support of the project. We particularly wish to thank D. Scharffe for the operation of the container and C. Koeppel for the handling of the whole air sampler. We would also like to thank J. Lelieveld, M. Lawrence, T. Rhee and A. Rauthe-Schöch for many insightful discussions of the data.

The service charges for this open access publication have been covered by the Max Planck Society.

Edited by: T. J. Dunkerton 


\section{References}

Andreae, M. O. and Merlet, P.: Emission of Trace Gases and Aerosols From Biomass Burning, Global Biogeochem. Cy., 15955-15966, doi:10.1029/2000GB001382, 2001.

Assonov, S., Taylor, P., and Brenninkmeijer, C. A.: A system for high quality $\mathrm{CO}_{2}$ isotope analysis of air samples collected by the CARIBIC Airbus A340-600, Rapid Commun. Mass Sp., 23, 1347-1363, 2009.

Atkinson, R. and Arey, J.: Atmospheric Degradation of Volatile Organic Compounds, Chem. Rev., 103, 4605-4638, 2003.

Atkinson, R., Baulch, D. L., Cox, R. A., Hampson, R. F., Kerr, J. A., Rossi, M. J., and Troe, J.: Evaluated kinetic and photochemical data for atmospheric chemistry, supplement VI, IUPAC Subcommittee on Gas Kinetic Data Evaluation for Atmospheric Chemistry, J. Phys. Chem. Ref. Data, 26, 1329-1499, 1997.

Baker, A. K., Slemr, F., and Brenninkmeijer, C. A. M.: Analysis of non-methane hydrocarbons in air samples collected aboard the CARIBIC passenger aircraft, Atmos. Meas. Tech., 3, 311-321, doi:10.5194/amt-3-311-2010, 2010.

Bhat, G. and Narashima, N.: Indian summer monsoon experiments, Current Science, 93, 153-164, 2007.

Bottenheim, J. W., Brickell, P. C., Dann, T. F., Wang, D. K., Hopper, F., Gallant, A. J., Anlauf, K. G., and Wiebe, H. A.: Nonmethane hydrocarbons and CO during PACIFIC '93, Atmos. Environ., 31, 2079-2087, 1997.

Brenninkmeijer, C. A. M., Crutzen, P., Boumard, F., Dauer, T., Dix, B., Ebinghaus, R., Filippi, D., Fischer, H., Franke, H., Frieß, U., Heintzenberg, J., Helleis, F., Hermann, M., Kock, H. H., Koeppel, C., Lelieveld, J., Leuenberger, M., Martinsson, B. G., Miemczyk, S., Moret, H. P., Nguyen, H. N., Nyfeler, P., Oram, D., O'Sullivan, D., Penkett, S., Platt, U., Pupek, M., Ramonet, M., Randa, B., Reichelt, M., Rhee, T. S., Rohwer, J., Rosenfeld, K., Scharffe, D., Schlager, H., Schumann, U., Slemr, F., Sprung, D., Stock, P., Thaler, R., Valentino, F., van Velthoven, P., Waibel, A., Wandel, A., Waschitschek, K., Wiedensohler, A., Xueref-Remy, I., Zahn, A., Zech, U., and Ziereis, H.: Civil Aircraft for the regular investigation of the atmosphere based on an instrumented container: The new CARIBIC system, Atmos. Chem. Phys., 7, 4953-4976, doi:10.5194/acp-7-4953-2007, 2007.

Carmichael, G. R., Tang, Y., Kurata, G., Uno, I., Streets, D. G., Thongboonchoo, N., Woo, J.-H., Guttikunda, S., White, A., Wang, T., Blake, D. R., Atlas, E., Fried, A., Potter, B., Avery, M. A., Sachse, G. W., Sandholm, S. T., Kondo, Y., Talbot, R. W., Bandy, A., Thorton, D., and Clarke, A. D.: Evaluating regional emission estimates $\mathrm{u}$ sing the TRACE-P observations, J. Geophys. Res., 108(D21), 8810, doi:10.1029/2002JD003116, 2003.

Chen, P.: Isentropic cross-tropopause mass exchange in the extratropics, J. Geophys. Res., 100, 16661-16674, doi:10.1029/ 95JD01264, 1995.

de Gouw, J. A., Warneke, C., Scheeren, H. A., van der Veen, C., Bolder, M., Scheele, M. P., Williams, J., Wong, S., Lange, L., Fischer, H., and Lelieveld, J.: Overview of the trace gas measurements on board the Citation aircraft during the intensive field phase of INDOEX, J. Geophys. Res., 106, 28453-28467, 2001.

Derwent, R. G., Davies, T. J., Delaney, M., Dollard, G. J., Field, R. A., Dumitrean, P., Nason, P. D., Jones, B. M. R., and Pepler, S. A.: Analysis and interpretation of the continuous hourly monitoring data for $26 \mathrm{C}_{2}-\mathrm{C}_{8}$ hydrocarbons at 12 United Kingdom sites during 1996, Atmos. Environ., 34, 297-312, 2000.
Devasthale, A. and Fueglistaler, S.: A climatological perspective of deep convection penetrating the TTL during the Indian summer monsoon from the AVHRR and MODIS instruments, Atmos. Chem. Phys., 10, 4573-4582, doi:10.5194/acp-10-45732010, 2010.

Fu, R., Hu, Y., Wrigh, J. S., Jiang, J. H., Dickinson, R. E., Chen, M., Filipiak, M., Read, W. G., Waters, J. W., and Wu, D. L.: Short circuit of water vapor and polluted air to the global stratosphere by convective transport over the Tibetan Plateau, P. Natl. Acad. Sci. USA, 103, 5664-5669, doi:10.1073/pnas.0601584103, 2006.

Fujinami, H. and Yasunari, T.: Submonthly Variability of Convection and Circulation over and around the Tibetan Plateau during the Boreal Summer, J. Meteor. Soc. Japan, 82, 1545-1564, 2004.

Helmig, D., Tanner, D. M., Honrath, R. E., Owen, R. C., and Parrish, D. D.: Nonmethane hydrocarbons at Pico Mountain, Azores: 1. Oxidation chemistry in the North Atlantic region, J. Geophys. Res., 113, D20S91, doi:10.1029/2007JD008930, 2008.

Hoskins, B. J. and Rodwell, M. J.: A Model of the Asian Summer Monsoon. Part I: The Global Scale., J. Atmos. Sci., 52, 13291340, doi:10.1175/1520-0469(1995)052, 1995.

Hsu, H.-H., Terng, C.-T., and Chen, C.-T.: Evolution of LargeScale Circulation and Heating during the FirstTransition of Asian Summer Monsoon., J. Climate, 12, 793-810, doi:10.1175/ 15200442(1999)012, 1999. bibitem IMD: Southwest Monsoon 2008: End of Season Report, India Meteorological Department, NewDelhi, India, 2008.

Jobson, B. T., Berkowitz, C. M., Kuster, W. C., Goldan, P. D., Williams, E. J., Fesenfeld, F. C., Apel, E. C., Karl, T., Lonneman, W. A. and D. Riemer, D.: Hydrocarbon source signatures in Houston, Texas: Influence of the petrochemical industry, J. Geophys. Res., 109, D24305, doi:10.1029/2004JD004887, 2004.

Joseph, P. V., Sooraj, K. P., and Rajan, C. K.: The summer monsoon onset process over South Asia and an objective method for the date of monsoon onset over Kerala, Int. J. Climatol., 26, 18711893, doi:10.1002/joc.134, 2006.

Krishnamurti, T. N. and Bhalme, H. N.: Oscillations of a Monsoon System. Part I. Observational Aspects., J. Atmos. Sci., 33, 19371954, doi:10.1175/1520-0469(1976)033, 1976.

Krishnamurti, T. N., Biswas, M. K., and Rao, D. V. B.: Vertical extension of the Tibetan high of the Asian summer monsoon, Tellus A, 60, 1038-1052, doi:10.1111/j.1600-0870.2008.00359.x, 2008.

Lal, S., Naja, M., and Subbaraya, B. H.: Seasonal variations in surface ozone and its precursors over an urban site in India, Atmos. Environ., 34, 2713-2724, 2000.

Lal, S., Sahu, L.K., Venkataramani, S., Rajesh, and T.A., Modh, K.S.: Distributions of $\mathrm{O}_{3}, \mathrm{CO}$ and $\mathrm{NMHCs}$ over the rural sites in central India, J. Atmos. Chem., 61, 73-84, 2008.

Lawrence, M. G. and Lelieveld, J.: Atmospheric pollutant outflow from southern Asia: a review, Atmos. Chem. Phys., 10, 1101711096, doi:10.5194/acp-10-11017-2010, 2010.

Lawrence, M. G., Rasch, P. J., von Kuhlmann, R., Williams, J., Fischer, H., de Reus, M., Lelieveld, J., Crutzen, P. J., Schultz, M., Stier, P., Huntrieser, H., Heland, J., Stohl, A., Forster, C., Elbern, H., Jakobs, H., and Dickerson, R. R.: Global chemical weather forecasts for field campaign planning: predictions and observations of large-scale features during MINOS, CONTRACE, and INDOEX, Atmos. Chem. Phys., 3, 267-289, doi:10.5194/acp-3- 
267-2003, 2003.

Lelieveld, J., Crutzen, P. J., Ramanathan, V., Andreae, M. O., Brenninkmeijer, C. A. M., Campos, T., Cass, G. R., Dickerson, R. R., Fischer, H., de Gouw, J. A., Hansel, A., Jefferson, A., Kley, D., de Laat, A. T. J., Lal, S., Lawrence, M. G., Lobert, J. M., Mayol-Bracero, O. L., Mitra, A. P., Novakov, T., Oltmans, S. J., Prather, K. A., Reiner, T., Rodhe, H., Scheeren, H. A., Sikka, D., and Williams, J.: The Indian Ocean Experiment: Widespread Air Pollution from South and Southeast Asia, Science, 291, 10311036, doi:10.1126/science.1057103, 2001.

Lelieveld, J., Berresheim, H., Borrmann, S., Crutzen, P. J., Dentener,F. J., Fischer, H., Feichter, J., Flatau, P. J., Heland, J., Holzinger, R., Korrmann, R., Lawrence, M. G., Levin, Z., Markowicz, K. M., Mihalopoulos, N., Minikin, A., Ramanathan, V., de Reus, M., Roelofs, G. J., Scheeren, H. A., Sciare, J., Schlager, H., Schultz, M., Siegmund, P., Steil, B., Stephanou, E. G., Stier, P., Traub, M., Warneke, C., Williams, J., and Ziereis, H.: Global Air Pollution Crossroads over the Mediterranean, Science, 298, 794-799, doi:10.1126/science.1075457, 2002.

Liu, Y., Wang, Y., Liu, X., Cai, Z., and Chance, K.: Tibetan middle tropospheric ozone minimum in June discovered from GOME observations, Geophys. Res. Lett., 36, L05814, doi:10.1029/2008GL037056, 2009.

McKeen, S. A. and Liu, S. C.: Hydrocarbon ratios and photochemical history of air masses, Geophys. Res. Lett., 20(21), 23632366, 1993.

Ohara, T., Akimoto, H., Kurokawa, J., Horii, N., Yamaji, K., Yan, X., and Hayasaka, T.: An Asian emission inventory of anthropogenic emission sources for the period 1980-2020, Atmos. Chem. Phys., 7, 4419-4444, doi:10.5194/acp-7-4419-2007, 2007.

O'Sullivan, D. A.: Temporal and spatial variability of halogenated compounds and other trace gases, Ph.D. thesis, University of East Anglia, 2007.

Park, M., Randel, W. J., Kinnison, D. E., Garcia, R. R., and Choi, W.: Seasonal variation of methane, water vapor, and nitrogen oxides near the tropopause: Satellite observations and model simulations, J. Geophys. Res., 109, D3302, doi:10.1029/2003JD003706, 2004.

Park, M., Randel, W. J., Emmons, L. K., Bernath, P. F., Walker, K. A., and Boone, C. D.: Chemical isolation in the Asian monsoon anticyclone observed in Atmospheric Chemistry Experiment (ACE-FTS) data, Atmos. Chem. Phys., 8, 757-764, doi:10.5194/acp-8-757-2008, 2008.

Park, M., Randel, W. J., Emmons, L. K., and Livesey, N. J.: Transport pathways of carbon monoxide in the Asian summer monsoon diagnosed from Model of Ozone and Related Tracers (MOZART), J. Geophys. Res., 114, D08303, doi:10.1029/2008JD010621, 2009.

Parrish, D. D., Hahn, C. J., Williams, E. J., Norton, R. B., Fehsensfeld, F. C., Singh, H. B., Shetter, J. D., Gandrud, B. W., and Ridley, B. A.: Indications of photochemical histories of Pacific air masses from measurements of atmospheric trace species at Point Arena, California, J. Geophys. Res., 97, 15883-15901, 1992.

Parrish, D., Trainer, M., Young, V., Goldan, P. D., Custer, W. C., Jobson, B. T., Fehsenfeld, F. C., Lonneman, W. A., Zika, R. D., Farmer, C. T., Riemer, D. D., and Rodgers, M. O.: Internal consistency tests for evaluation of measurements of anthropogenic hydrocarbons in the troposphere, J. Geophys. Res., 103(D17),
22339-22359, 1998.

Parrish, D. D., Dunlea, E. J., Atlas, E. L., Schauffler, S., Donnelly, S., Stroud, V., Goldstein, A. H., Millet, D. B., McKay, M., Jaffe, D. A., Price, H. U., Hess, P. G., Flocke, F., and Roberts, J. M.: Changes in the photochemical environment of the temperate North Pacific troposphere in response to increased Asian emissions, J. Geophys. Res., 109, D23S18, doi:10.1029/2004JD004978, 2004.

Parrish, D. D., Stohl, A., Forster, C., Atlas, E. L., Blake, D. R., Goldan, P. D., Kuster, W. C., and de Gouw, J. A.: Effects of mixing on hydrocarbon mixing ratios in the troposphere, J. Geophys. Res., 112, D10S34, doi:10.1029/2006JD007583, 2007.

Randel, W. J. and Park, M.: Deep convective influence on the Asian summer monsoon anticyclone and associated tracer variability observed with Atmospheric Infrared Sounder (AIRS), J. Geophys. Res., 111, D12314, doi:10.1029/2005JD006490, 2006.

Randel, W. J., Park, M., Emmons, L., Kinnison, D., Bernath, P., Walker, K. A., Boone, C., and Pumphrey, H.: Asian Monsoon Transport of Pollution to the Stratosphere, Science, 328, 611613, doi:10.1126/ science.1182274, 2010.

Roberts, J .M., Fehsenfeld, F. C., Liu, S. C., Bollinger, M. J., Hahn, C., Albritton, D. L., and Sievers, R. E.: Measurements of aromatic hydrocarbon ratios and $\mathrm{NO}_{\mathrm{x}}$ concentrations in the rural atmosphere: Observations of air mass photochemical aging and $\mathrm{NO}_{\mathrm{x}}$ removal, Atmos. Environ., 18, 2421-2432, 1984.

Rudolph, J. and Johnen, F. J.: Measurements of light atmospheric hydrocarbons over the Atlantic in regions of low biological activity, J. Geophys. Res., 95, 20583-205919, 1990.

Sahu, L. K. and Lal, S.: Distributions of $\mathrm{C}_{2}-\mathrm{C}_{5}$ NMHCs and related trace gases at a tropical urban site in India, Atmos. Environ., 40, 880-891, 2006a.

Sahu, L. K. and Lal, S.: Characterization of $\mathrm{C}_{2}--\mathrm{C}_{4}$ NMHCs distributions at a high altitude tropical site in India, J. Atmos. Chem., 54, 161-175, 2006b.

Sanjeeva Rao, P.: Arabian Sea Monsoon Experiment: An Overview, Mausam, 56, 1-6, 2005.

Scheele, M., Siegmund, P., and Velthoven, P. V.: Sensitivity of trajectories to data resolution and its dependence on the starting point: In or outside a tropopause fold, Meteorol. Appl., 3, 267273, doi:10.1002/met.5060030308, 1996.

Scheeren, H. A., Lelieveld, J., Roelofs, G. J., Williams, J., Fischer, H., de Reus, M., de Gouw, J. A., Warneke, C., Holzinger, R., Schlager, H., Klüpfel, T., Bolder, M., van der Veen, C., and Lawrence, M.: The impact of monsoon outflow from India and Southeast Asia in the upper troposphere over the eastern Mediterranean, Atmos. Chem. Phys., 3, 1589-1608, doi:10.5194/acp-31589-2003, 2003.

Schuck, T. J., Brenninkmeijer, C. A. M., Slemr, F., Xueref-Remy, I., and Zahn, A.: Greenhouse gas analysis of air samples collected onboard the CARIBIC passenger aircraft, Atmos. Meas. Tech., 2, 449-464, doi:10.5194/amt-2-449-2009, 2009.

Schuck, T. J., Brenninkmeijer, C. A. M., Baker, A. K., Slemr, F., von Velthoven, P. F. J., and Zahn, A.: Greenhouse gas relationships in the Indian summer monsoon plume measured by the CARIBIC passenger aircraft, Atmos. Chem. Phys., 10, 39653984, doi:10.5194/acp-10-3965-2010, 2010.

Spivakovsky, C. M., Logan, J. A., Montzka, S. A., Balkanski, Y. J., Foreman-Fowler, M., Jones, D. B. A., Horowitz, L.W., Fusco, A. C., Brenninkmeijer, C. A. M., Prather, M. J., Wofsy, S. C., and 
McElroy, M. B.: Three-dimensional climatological distribution of tropospheric OH: Update and evaluation, J. Geophys. Res., 105, 8931-8980, doi:10.1029/1999JD901006, 2000.

Streets, D. G., Bond, T. C., Carmicheal, G. R., Fernandes, S. D., Fu, Q., He, D., Klimont, Z., Nelson, S. M., Tsai, N. Y., Wang, M. Q., Woo, J. -H., and Yarber, K. F.: An inventory of gaseous and primary aerosol emissions in Asia in the year 2000, J. Geophys. Res., 108(D21), 8809, doi:10.1029/2002JD003093, 2003.

Traub, M. and Lelieveld, J.: Cross-tropopause transport over the eastern Mediterranean, J. Geophys. Res., 108, 4712, doi:10.1029/2003JD003754, 2003.

van Velthoven, P. F. J.: Meteorological analysis of CARIBIC by KNMI, available at: http://www.knmi.nl/samenw/campaign support/CARIBIC/, 2009.
Wang, B., Ding, Q., and Joseph, P. V.: Objective Definition of the Indian Summer Monsoon Onset, J. Climate, 22, 3303-3316, doi:10.1175/2008JCLI2675.1, 2009.

Xiong, X., Houweling, S., Wei, J., Maddy, E., Sun, F., and Barnet, C.: Methane plume over south Asia during the monsoon season: satellite observation and model simulation, Atmos. Chem. Phys., 9, 783-794, doi:10.5194/acp-9-783-2009, 2009.

Yevich, R. and Logan, J. A.: An assessment of biofuel use and burning of agricultural waste in the developing world, Global Biogeochem. Cy., 17, 1095, doi:10.1029/202GB001952, 2003. 